\title{
INTELLECTUAL CAPITAL \\ IN NON-PUBLIC HIGHER EDUCATION INSTITUTIONS - THE MANAGERIAL PERSPECTIVE
}

JAN FAZLAGIĆ

\begin{tabular}{l|l} 
& $\begin{array}{l}\text { Poznan University of Economics } \\
\text { e-mail: Jan.fazlagic@ue.poznan.pl }\end{array}$ \\
$\begin{array}{l}\text { RECEIVED } \\
\text { ACCEPTED }\end{array}$ & $\begin{array}{l}1 \text { March } 2015 \\
1 \text { June } 2015\end{array}$ \\
JEL & 120,125 \\
KESSIFICATION & $\begin{array}{l}\text { intellectual capital, higher education institutions, knowledge management } \\
\text { In the new knowledge-based economy intellectual capital has become the key asset for sustainability and } \\
\text { achieving competitive advantage. "Knowledge" is the main output as well as input in these institutions. This } \\
\text { research paper presents the research findings describing selected elements of intellectual capital (IC) in non- } \\
\text { public higher education institutions in Poland, namely students and managers of higher education institutions. } \\
\text { A review of definitions of IC is provided accompanied by comments relating to the situation of higher education } \\
\text { institutions. Better management practice regarding IC allow universities to be in a better position to compete } \\
\text { globally and in the home market. }\end{array}$
\end{tabular}

\section{Introduction}

The research project was aimed at developing a method of intellectual capital (IC) measurement for nonpublic higher education institutions in Poland. This paper presents the results of a survey conducted among the management staff of non-public HEl's, namely rectors, deputy rectors, deans, chancellors and other professionals occupying middle- to-top-management positions in HEls. The general population is estimated at approximately 
2.5-3.0 thousand in Poland. The request to participate in the survey was sent to all HEls and was additionally promoted (as a link to an on-line questionnaire) in several national websites and newsletters directed to the management staff in HEls. A total of 51 , or approximately $1.5-2.0 \%$ of the general population of respondents replied to the survey. The questionnaire consisted of 17 questions. Some respondents did not reply to some questions. Nearly half of the respondents were born in the year 1960 or earlier. Only 3 respondents were born in 1981 or later. Twenty questionnaires were filled in by rectors or deans. The research sample was evenly distributed amidst the 16 Polish regions according to their population. The majority of respondents were representing HEls specializing in economics, management and humanities. Other respondents were representing HEls with student populations between 1,001-5,000 students. There were 5 very small HEls (300 or less students) in the research sample and 4 schools with $7,000+$ student populations.

\section{The problem of defining IC in Higher Education Institutions}

The majority of the definitions of IC and related concepts have been developed primarily for the benefit of business organizations. One of the main motives for most IC measurement exercises, at least at the earlier stages (i.e., in the 1990s and early 2000s) of this domain of management science. As a result, those definitions may be not fully relevant to tertiary education. Even though there are many for-profit HEls, they cannot be compared with regular business enterprises. The problem of definition of IC in HEls is further highlighted in Table 1.

Many aspects of IC in HEls are very specific only to the education sector. For example, until recently internationalization was not a top of rectors' agendas in universities. Only in the last 10-15 years did their concept become the strategic issue, even in small- to medium-sized local HEls. There are also some elements of IC in HEls which have always remained the "core business" - namely "research" and "teaching". Another important trend that is currently shaping the higher education landscape are the mergers and acquisitions (see for example: Bennennetot et al., 2015). But even the concepts of research and teaching are changing. Quality teaching in universities means involvement of practitioners and academic entrepreneurship. In the same vein, quality research is now conducted in different circumstances than 20 years ago or earlier. The most desirable elements of IC in $\mathrm{HEI}$ are those which create synergies, for example, faculties with good research track records, extensive networking capital, international exposure, etc. Unlike in the case of a business organization the intellectual capital of a HEI cannot be divided into divisions. The best universities are those which employ multitalented staff who employ their tacit knowledge in more than one activity area. For the purpose of this discussion, it would be useful to introduce the concept of 'synergy' IC, which would account for all the instances of multiple employment of intangible assets, e.g.: an academic teacher starting a university spin-off company with an international partner and conducting research studies based on this project.

HEls rely heavily on structural capital (which has not always been the case). In the past the main asset of a university was a (sometimes very small) community of professors. Today, in the internet area, the access to the best knowledge is almost free. What really counts is the intellectual ecosystem co-created by professors, students, administration staff and business organizations cooperating with a university as well as other universities (including international ones). A specific asset worth mentioning is the brand of a HEI. The importance of brand in higher education has been strengthening as a side-effect of globalization in tertiary education. 
Table 1. Definitions of Intellectual Capital and their application in tertiary education

\begin{tabular}{|c|c|c|c|}
\hline Authors of definition & Term concept & Definition & $\begin{array}{l}\text { Relation to intellectual capital in a higher education } \\
\text { institution }\end{array}$ \\
\hline Itami (1991) & Invisible assets & $\begin{array}{l}\text { "Intangible assets are invisible assets that include } \\
\text { a wide range of activities such as technology, } \\
\text { consumer trust, brand image, corporate culture, } \\
\text { and management skills" }\end{array}$ & $\begin{array}{l}\text { This definition emphasizes the role of "activities" } \\
\text { and does not mention "stocks" such as "tradition", } \\
\text { "reputation" (of a HEl) }\end{array}$ \\
\hline Hall (1992: 136) & Intangible asset & $\begin{array}{l}\text { "Intangible assets are value drivers that transform } \\
\text { productive resources into value-added assets" }\end{array}$ & $\begin{array}{l}\text { The definition emphasizes "added value". HEl's; } \\
\text { added-value is measured by such abstract } \\
\text { concepts as "contribution to development } \\
\text { of science", "personal growth and well-being } \\
\text { of graduates" }\end{array}$ \\
\hline Smith (1994) & $\begin{array}{l}\text { Intellectual } \\
\text { property }\end{array}$ & $\begin{array}{l}\text { "Intangible assets are all the elements } \\
\text { of a business enterprise that exist in addition } \\
\text { to working capital and tangible assets. They are } \\
\text { the elements, after working capital and tangible } \\
\text { assets, that make the business work and are often } \\
\text { the primary contributors to the earning power } \\
\text { of the enterprise. Their existence is dependent } \\
\text { on the presence, or expectation, of earnings" }\end{array}$ & $\begin{array}{l}\text { The definition focuses strictly on business } \\
\text { operations and cannot be applied for HEI without } \\
\text { modifications. Many HEls do not operate for the } \\
\text { purpose of "earnings". Financial surplus in HEI } \\
\text { is often transferred into IC, e.g., in the form } \\
\text { of supporting more research and publication } \\
\text { activities }\end{array}$ \\
\hline Brooking (1997: 13) & Intellectual capital & $\begin{array}{l}\text { IC as "market assets, human-centered assets, } \\
\text { intellectual property assets, and infrastructure } \\
\text { assets" }\end{array}$ & $\begin{array}{l}\text { This definition is very relevant to the situation } \\
\text { of HEls with the exception of the term "market } \\
\text { assets" }\end{array}$ \\
\hline $\begin{array}{l}\text { Edvinsson and } \\
\text { Malone (1997: 22) }\end{array}$ & $\begin{array}{l}\text { Intellectual capital } \\
\text { and intangible } \\
\text { assets }\end{array}$ & $\begin{array}{l}\text { "Intangible assets are those that have no physical } \\
\text { existence but are still of value to the company" }\end{array}$ & $\begin{array}{l}\text { In the case of a university, the physical assets are } \\
\text { always a negligible part of its total value. Even } \\
\text { in technology-intensive research institutions, what } \\
\text { really counts are the specialized professionals } \\
\text { who possess the knowledge how to utilize the } \\
\text { often expensive research labs for the benefit } \\
\text { of development of science }\end{array}$ \\
\hline Sveiby (1997: 10) & Immaterial values & $\begin{array}{l}\text { IC has three dimensions (employee competence, } \\
\text { internal structure and external structure) }\end{array}$ & $\begin{array}{l}\text { The concept developed by Karl-Erik Sveiby } \\
\text { has been very popular and is fully applicable } \\
\text { for measuring IC in HEls }\end{array}$ \\
\hline $\begin{array}{l}\text { Harrison and Sullivan } \\
(2000: 34)\end{array}$ & Intellectual capital & "Knowledge that can be converted into profit" & $\begin{array}{l}\text { IC in HEls goes beyond "knowledge" (e.g. brand } \\
\text { of a HEI, student community, tradition, etc.) and } \\
\text { does not have to be transferred into "profit" (it can } \\
\text { be converted into more knowledge, for example } \\
\text { (by means of investment into research activities) }\end{array}$ \\
\hline FASB NN (2001: 6) & Intangible assets & $\begin{array}{l}\text { "Intangible assets are non current, nonfinancial } \\
\text { claims to future benefits that lacks a physical } \\
\text { or financial term" }\end{array}$ & $\begin{array}{l}\text { Although the definition has been developed } \\
\text { by a financial institution, it is surprisingly relevant } \\
\text { to the situation of HEls }\end{array}$ \\
\hline $\begin{array}{l}\text { Mouritsen et al. } \\
(2004: 48)\end{array}$ & Intellectual capital & $\begin{array}{l}\text { IC mobilizes 'things' such as employees, } \\
\text { customers, IT, managerial work and knowledge. } \\
\text { IC cannot stand by itself, as it merely provides } \\
\text { a mechanism that allows the various assets } \\
\text { to be bonded together in the productive process } \\
\text { of the firm }\end{array}$ & $\begin{array}{l}\text { The statement "IC cannot stand by itself" does not } \\
\text { usually hold true in the case of HEls }\end{array}$ \\
\hline
\end{tabular}

Source: own compilation, definitions of IC derived from Choong (2008). 


\section{Research findings}

The respondents were requested to "build" their own definition of IC by choosing some components from a list of descriptions. The most frequently indicated components were:

- the ability to develop didactic, organizational and marketing innovations,

- a sum of the talents of HEl's employees,

- a sum of the knowledge assets contained in the brains of employees,

- the unique personalities amidst academic teachers,

- the organizational culture of the HEl.

The least frequently quoted components of IC were:

- teaching programmes,

- difference between book and market value of a HEI (market-to-book ratio),

- discounted future cash flows generated by the HEl for its owners,

- reputation among students,

- reputation among academic teachers.

As mentioned earlier, Poland has an exceptionally high number of HEls. Yet the demographic downturn makes the financial existence of many of them impossible, not to mention their inability to attract any substantial investments. Demographic problems are common in many other European countries, e.g., Turkey, Germany and Italy. The consolidation of HEls looms as a natural and logical trend in the second decade of the 21 st century. The structure and, especially the relative value of different components of IC must complement the information on the (estimated) value of IC. Unfortunately most researchers analyzing IC do not go into strengths to investigate the value or the weight in the "IC mix" of different components. It is difficult to enumerate all the components of $\mathrm{IC}$, but it is even more difficult to estimate their relative weight. How important is the brand of a HEI compared with the knowledge of its academic staff? Can increased quality candidates compensate for the drop in the number of enrollments? How important are research skills compared to teaching skills among faculty? These are but a few questions which illustrate how much more research would have to be conducted in the future to reveal the structure of IC.

The market premium over the book price may depend on various factors. The next question asked the respondents about the sources of value (IC components). The respondents were presented with a list of components from which they could indicate the three most important value-creating factors. The least popular factors were "teaching skills of teachers" (10 responses), attractive organizational culture (10), IT infrastructure (7), other (5), efficiency of the students' office, and marketing skills in the HEl's marketing department (4). The last response is especially indicative. Polish schools are investing heavily in promoting their educational offerings, yet the knowledge of the marketing staff is not highly appreciated. The relatively low rank of teaching skills of teachers also indicates the dominance of external structure over individual competences (Karl-Erik Sveiby made a distinction among three components of IC, namely: individual competence (human capital), internal structure and external structure (market capital) See: (Sveiby, 1997)). Management of higher education institutions is a demanding job requiring the application of a wide range of knowledge, skills and competences. The strategy of an $\mathrm{HEl}$ is implemented through decisions. Limited tangible and intangible resources require HEl's managers to choose constantly among many options and to solve strategic dilemmas. Scarce resources often make the manager choose the lesser evil, e.g., allocating resources for staff development vs. increasing the marketing efforts. Therefore, from the investigator's 
point of view it would be unproductive to inquire about strategic issues by asking questions such as: "What is the most important?". A more reasonable research question should be based on the assumption that HEl managers must constantly prioritize and solve strategic puzzles related to such dilemmas as:

- creating short-term vs. long term strategic goals,

- providing a student-friendly learning environment vs. focusing on teaching outcomes and academic discipline,

- achieving financial results (retention of low-performing students at the cost of lowering teaching standards) vs. keeping academic standards high even at the cost of students dropping out,

- striving for moral integrity and development of character vs. "letting-it-off" by accepting a laissez-faire, low demands culture,

- providing a good infrastructure and working environment for teachers vs. providing a good infrastructure and working environment for students.

The above-mentioned strategic dilemmas were identified in the process of in-depth interviews which were conducted prior to the survey as well as from 15+ years of experience of the author as a manager and academic teacher in HEls. Based on the above mentioned strategic dilemmas, the respondents were asked about their preferences. Over $50 \%$ of management staff in HEls believe that transferring skills useful in the current job market is more important for them than transferring skills which will be useful in 5-10 years from now. This approach is rational from the HEl's perspective but not necessarily rational from the job market perspective. If too many universities neglect a long term orientation, the chances for job-market misfits increase. The role of state regulations is crucial here. On one hand universities in most OECD countries are independent, but a lack of coordination and pressure from the governments "not to produce unemployed graduates" may lead the universities to neglect long term employability skills among students. Over $50 \%$ respondents are of the opinion that providing a friendly atmosphere for studying is less important than meeting academic standards. The results show that over $1 / 3(35 \%)$ of respondents considers discipline as a more important priority than a friendly atmosphere. The next question touched upon the issue of the prevalence of financial goals in the strategy of non-public higher education institutions. How deeply is the academic ethos ingrained in the culture of private organizations? Will private universities forsake their academic mission in order to stay profitable? Almost half of the respondents agree that financial goals do not outweigh the importance of the academic ethos. But $1 / 3$ of the managerial staff admits that, for the sake of financial results "we will come to terms with lower academic standards in some of our courses in order to avoid students' dropout". Helping students prepare for adulthood (e.g. by enforcing their personal skills such as reliability, punctuality, perseverance, responsibility, etc.) is not chosen as a factor which outweighs the importance of positive educational experience (51\%). Over $1 / 2$ of respondents are of the opposite opinion and $14 \%$ are undecided. For most respondents, it is more important. Over $75 \%$ of respondents do not agree with the statement that attractive working conditions for faculty are more important than quality infrastructure. The assumption that higher satisfaction of employees translates into higher satisfaction of clients has been investigated. This research question also relates to Clark's concept of academic oligarchy. According to Clark (1983) academic oligarchy is one of the three forces in a tertiary education system which explains its set-up (other being the state authority and the market). Clark examines how different interest groups both inside and outside the university shape and subvert the management of change. Within the university, Clark notes the tensions between the "enterprise" and the "discipline" and at the system level between the state authority, the market and the academic oligarchy. The dilemma "employees or 
clients?" arises also in the business environment. For example the famous airline Southwest Airlines promotes employee satisfaction as the means to achieve customer satisfaction (Freiberg, 1998; Gittel, 2005; Gummesson, 2012). In Poland for example many non-public universities employ professors who are members of faculties at public institutions (it is allowed by law as long as one professor does not have more than two job contracts with different universities). Therefore public and non-public universities compete for academic staff by offering better work environments (with salaries being equal).

There is agreement among the majority of researchers on IC regarding its structure. It is assumed that there are three main components of IC:

- human capital,

- organizational capital,

- customer capital.

These three elements were used as a basis for a more in-depth analysis of the quality of IC in HEls. The respondents were requested to provide their opinions on selected factors relating to

- human capital,

- organizational capital,

- customer capital.

The question how to invest limited resources is crucial. The opening-up of the black box as presented here provides a better understanding of IC structure. Some components of IC (human capital, organizational capital, customer capital) may be valued by one group of stakeholders (e.g., management staff) but not appreciated by another (e.g., students). Many researchers in the field of IC took for granted the so called three-way model of IC originated by Karl-Erik Sveiby. Is the classification appropriate for HEls? Are 'students' really part of external structure? But what about PhD students? They are obviously HEl's clients (external structure) but, at the same time they are junior researchers (internal structure).

The purpose of this part of the questionnaire was to gain a better understanding what really makes up the IC of an HEI. Many researchers provide lists of components of educational institutions, but it is not clear what the weight of them in the total pool is. Does creativity of academic teachers outweigh the "large percentage of foreign academic teachers" (or in a more pragmatic context: is it better to hire a non-so-creative foreigner or a creative native teacher?). A list of some characteristics of academic staff was presented to the respondents who could select three characteristics. Such research approach allows the managers to create the 'ideal' profile of an academic teacher. Of course, the value of an HEl lies in its diversity; therefore, it would not be wise to limit the pool of desired competencies simply to the list below. The most advantageous features of faculty in HEls were "high percentage of creative professors with high intellectual curiously"; "active professors who bring academic atmosphere to student life", and reputable scientists working full time in the HEl".

The least popular answer was: "Professors commuting from distant (over $200 \mathrm{kms}$ ) locations". This answer was to test the management attitude towards employing professors who may be not so much attached to the local academic community. On the other hand such professors may offer added value by introducing different perspectives and viewpoints to the local community. The respondents did not recognize this characteristic of professors as important (only one indication). Equally little recognition was given the answer "Professors with their own business experience running their own enterprises". The professors with high media presence were also unrecognized as important contributors to IC. 
Human capital is just one of the three main components of IC. The managers of HEls were asked to indicate those features of internal structure which have the strongest impact on the competitiveness of the HEI. The three most important items could be checked from the following list:

- an environment which enables self-fulfillment,

- efficient IT suport,

- internationalisation - a large proportion of international students and teachers,

- competent leadership,

- the organisational proficiency of the administration personnel and dean's office,

- satisfaction derived from work with ambitious students,

- opportunities for self- development not offered by public HEls,

- financial support for personnel development offered by the HEl,

- quality facilities,

- professors actively conducting research in the academic community,

- good relations between management staff and faculty,

- brand recognition in the local community,

- a clear vision of the HEl's development,

- other.

\section{Students}

The last section of the survey was dedicated to the role of students in the creation of IC. Students are not merely "customers buying services". In the case of an HEl, students are co-creators of the academic value. They at least theoretically should be part of the academic life in various forms such as young entrepreneurs, junior researchers, members of on-campus student organizations, co-creators of the educational value, etc. The plethora of roles makes the students difficult to classify. In some of their roles they are may be classified as "human capital" (students conducting research projects within a $\mathrm{HEI}$ ), "internal structure" (students as co-producers of value with academic teachers) and finally their "traditional role - students as an element of external structure (market capital).

Even their roles within the external structure are multifaceted. Students may contribute to the creation of IC as 'part-time marketers' thorough word-of-mouth, including communication in social media. The respondents were asked to characterize the students who attended their HEl in the last two years. The question was indented to obtain the opinions of the management staff on the quality of students. The students were described as five types. Each type describes a certain kind of attitudes or behaviours which affect the quality of intellectual capital. Five characteristics of students were described:

1. Strongly motivated for self-development.

2. Focused on obtaining an academic degree.

3. Mediocre, lacking motivation for learning and not interested in self-development, lost in life.

4. Destructive, "loafers".

5. Displaying sufficient deficits in basic skills and cultural capital.

Only $5 \%$ respondents are of the opinion that almost all students ( $76-100 \%$ of academic community) belong to Type 1. A majority of respondents (88\%) are of the opinion that students focused solely on obtaining a B.A or M.A. degree constitute a large proportion of all students. Over $46 \%$ of respondents are of the opinion that the share of 
"mediocre, lacking motivation for learning and not interested in self-development, lost in life" students (Type 3) is higher than $25 \%$. The majority of respondents consider Type 4 students (destructive, loafers) as a small fraction of the academic community; $90 \%$ of management staff thinks that such students constitute a small proportion of all students.

In the past, when the enrollment rates for universities were low, and majority of secondary education graduates ended their education without obtaining a college degree, universities were populated by highlymotivated students, the majority of them with middle-class backgrounds. Today the universities in Poland have ceased to offer 'elite' education. The number of seats at universities exceeds the number of undergraduate student candidates. For example in 1980s and early 1990s some elitist public universities were in a position to offer a seat to 1 in 10 candidates and pursue a rigid selection process. Today, the same universities are forced to lower academic standards to attract even less skillful undergraduate student candidates. The challenge is not only the deficit in curricular knowledge but also the generally low cultural capital. Many Polish universities have prepared instructional videos for first year students on how to behave properly on campus. The culture clash between academic teachers and generation $Y$ students is often a source of frustration for both sides. The respondents were asked about the share of students displaying deficits in cultural capital. Some $56 \%$ of respondents are of the opinion that "students displaying significant deficits in basic knowledge and cultural capital" constitute more than $25 \%$ of total students at campus.

\section{Summary}

The research results presented in this paper are based on opinions of Polish higher education managers representing 51 Polish HEls, or approximately $7.5 \%$ of the general population. They may not be representative in all aspects but the main aim of the research study, to conduct a practice orientated analysis of key factors related to IC creation, was achieved. The main conclusions from the study are as follows:

In the face of globalization and internationalization of higher education, institutions' research on IC of universities is a necessity. University rankings are important in discovering the value of IC, but they often lack the local context and provide a one-size-fits-all measurement approach. The position of a university in a ranking list may be easily skewed. For example the recent jump in ranking lists by the University of Warsaw, Poland was achieved through the granting a Nobel Prize to one of its graduates from the pre-war period. It is dubious if such occurrence is of any value to the current quality of teaching or research.

Smaller HEls have no chance to be listed in Top 1000 best universities. Many of the criteria of the world rankings are simply abstract to them. Yet the value of IC for many HEls operating on regional scale cannot be underestimated.

The IC of a university has many specific features which make it distinct from other knowledge-intensive service providers.

\section{Acknowledgments}

The author would like to express his gratitude to Prof. Karl-Erik Sveiby for his insightful comments in e-mail correspondence on IC in August 2012. The author extends his gratitude to Dr. Windham Loopesko for proofreading of the draft version of this article. 
This research was supported by an the National Science Centre (NCN) grant N115 118739 in the years 2010-2012.

\section{References}

Bennennetot Pruvo, E., Estermann, T. \& Mason, P. (2015). Define Thematic Report: University Mergers in Europe. European University Association.

Choong, K.K. (2008). Intellectual capital: definitions, categorization and reporting models. Journal of Intellectual Capital, 9 (4): 609-638. Clark, B.R. (1983). The Higher Education Systems. Berkeley, California: University of California Press.

Freiberg, K. \& Freiberg, J. (1996). Nuts! Southwest Airlines' Crazy Recipe for Business and Personal Success. New York: Bard Press. Gittel, J.H. (2003). The Southwest Airlines Way. New York: Mc-Graw-Hill.

Gummesson, E. (1999). Total Relationship Marketing. Oxford: Butterworth-Heinemann.

Sveiby, KE. (1997). The New Organizational Wealth: Managing and Measuring Knowledge-based Asset. San Francisco: Berrett-Koehler. Sveiby, K.E. (2001). A Knowledge-based Theory of the Firm To guide Strategy Formulation. Journal of Intellectual Capital, 2 (4).

Tobin, J. (1969). A general equilibrium approach to monetary theory. Journal of Money Credit and banking, 1 (1), February.

Cite this article aS: Fazlagić, J. (2015). Intellectual Capital in non-public Higher Education Institutions - the Managerial Perspective. Szczecin University Scientific Journal, No. 872. Service Management, 15 (1): 31-39. 
